\title{
Article \\ Chemical Composition and Biological Activities of Oregano and Lavender Essential Oils
}

\author{
Chahla Benbrahim ${ }^{1, *}$, Mohammed Salih Barka ${ }^{1}\left(\mathbb{D}\right.$, Adriana Basile $^{2}$, Viviana Maresca ${ }^{2}$ (D) Guido Flamini $^{3}$ (D), \\ Sergio Sorbo $^{4}$, Federica Carraturo ${ }^{2} \mathbb{D}$, Rosaria Notariale ${ }^{5}$, Marina Piscopo ${ }^{2} \mathbb{D}$, Abdelmounaim Khadir ${ }^{1}$, \\ Asma Zatout $^{6}$ and Sara Mechaala ${ }^{7}$
}

check for updates

Citation: Benbrahim, C.; Barka, M.S.; Basile, A.; Maresca, V.; Flamini, G.; Sorbo, S.; Carraturo, F.; Notariale, R.; Piscopo, M.; Khadir, A.; et al.

Chemical Composition and Biological Activities of Oregano and Lavender Essential Oils. Appl. Sci. 2021, 11, 5688. https://doi.org/10.3390/ app11125688

Academic Editor: Natália Martins

Received: 24 May 2021

Accepted: 18 June 2021

Published: 19 June 2021

Publisher's Note: MDPI stays neutral with regard to jurisdictional claims in published maps and institutional affiliations.

Copyright: (c) 2021 by the authors. Licensee MDPI, Basel, Switzerland. This article is an open access article distributed under the terms and conditions of the Creative Commons Attribution (CC BY) license (https:/ / creativecommons.org/licenses/by/ $4.0 /)$.
1 Laboratory of Applied Microbiology in Food, Biomedical and Environment (LAMAABE), Department of Biology, University of Tlemcen, Tlemcen 13000, Algeria; mohammedsalih.barka@univ-tlemcen.dz (M.S.B.); abdelmounaim.Khadir@univ-tlemcen.dz (A.K.)

2 Department of Biology, Federico II University, 80126 Naples, Italy; adbasile@unina.it (A.B.); viviana.maresca@unina.it (V.M.); federica.carraturo@unina.it (F.C.); marina.piscopo@unina.it (M.P.)

3 Dipartimento di Chimica Bioorganica, Università di Pisa, Via Bonanno 33, 56126 Pisa, Italy; guido.flamini@farm.unipi.it

4 Ce.S.M.A. Department of Biology, University Federico II, 80126 Naples, Italy; sersorbo@unina.it

5 Department of Precision Medecine, School of Medecine, University of Campania "Luigi Vanitelli", Via de Crecchio, 80138 Naples, Italy; rosaria.notariale@unicampania.it

6 Laboratory of Microbiology and Plant Biology, Department of Biological Sciences, Faculty of Natural Sciences and Life, University of Abdlhamid Ibn Badis, Mostaganem 27000, Algeria; asma.zatout@univ-mosta.dz

7 Laboratory of Genetics, Biotechnology, and Valorization of Bio-resources (GBVB), Faculty of Exact Sciences and Sciences of Nature and Life, Mohamed Khider University, Biskra 07000, Algeria;

s.mechaala@univ-biskra.dz

* Correspondence: chahla.benbrahim@univ-tlemcen.dz

\begin{abstract}
Folk medicine uses wild herbs, especially from the Lamiaceae family, such as oregano and lavender, in the treatment of many diseases. In the present study, we investigated the antibacterial activity of the essential oils of Origanum glandulosum Desf. and Lavandula dentata L. against multidrugresistant Klebsiella pneumoniae strains. The chemical composition of essential oils and their effect on the ultrastructure of the tested bacteria and on the release of cellular components that absorb at $260 \mathrm{~nm}$ were studied. Furthermore, the cytotoxicity and the production of reactive oxygen species in human lymphocytes treated with essential oils were evaluated. Thymol (33.2\%) was the major constituent in $O$. glandulosum, and $\beta$-pinene $(17.3 \%)$ was the major constituent in $L$. dentata. We observed ultrastructural damage in bacteria and increased release of cellular material. Furthermore, ROS production in human lymphocytes treated with essential oils was lower than in untreated lymphocytes and no cytotoxicity was observed. Therefore, the essential oils of lavender and oregano could be used as a source of natural antibacterial and antioxidant agents with potential pharmacological applications.
\end{abstract}

Keywords: Origanum glandulosum; Lavandula dentata; Klebsiella pneumoniae; antibacterial activity; transmission electron microscopy TEM; cell viability; ROS

\section{Introduction}

Infections caused by multidrug-resistant bacteria have become a major global public health problem, particularly through the acquisition of new antibiotic resistance, a consequence of the excessive and inappropriate use of antibiotics [1,2]. Over the past 30 years, extended spectrum $\beta$-lactamases (ESBLs) have diffused in most species of Enterobacteriaceae. Previous European studies have shown that Klebsiella pneumoniae and E. coli were the species most frequently responsible for ESBL secretion [3], especially K. pneumoniae, part of the natural intestinal microflora, but regarded as an opportunistic pathogen $[4,5]$. The colonization of biological tissues by K. pneumoniae frequently causes a large variety of diseases [6-12]. 
Klebsiella pneumoniae, belonging to the Enterobacteriaceae family, is a common opportunistic hospital-associated pathogen, accounting for about one-third of all Gram infections overall. It is involved in extra-intestinal infections including urinary tract infections, cystitis, pneumoniae, surgical wound infections, and life-threatening infections such as endocarditis and septicemia. Along with its high prevalence, K. pneumoniae is a major source of antibiotic resistance. Data retrieved from the European Antimicrobial Resistance Surveillance Network (http:/ / atlas.ecdc.europa.eu/public/index.aspx?Instance=GeneralAtlas accessed on 1 May 2021) for the years 2005-2015 show non-susceptible rates for K. pneumoniae and Escherichia coli against the four major antibiotic classes, namely the third-generation cephalosporins, aminoglycosides, fluoroquinolones, and carbapenems.

It is therefore urgent to make available new molecules with antibacterial effects and which can act against multidrug-resistant strains.

Natural substances are promising sources of alternatives drugs [13]. Essential oils have numerous activities, ranging from antibacterial and antiradical [14], insecticide, acaricide, antifungal, cytotoxic, antiviral, antiprotozoan, anthelmintic, antiseptic, and antiinflammatory $[15,16]$, antitumoral, antioxidant, antiallergic, anticonvulsant, antidepressant, contraceptive, antimutagen, analgesic, and diuretic [17], and anticancer activity as well as activity in preventing the development of cardiovascular and degenerative diseases [18]. Folk medicine uses wild herbs, especially from the Lamiaceae family, such as oregano and lavender, in the treatment of many illnesses [19].

Origanum glandulosum Desf. is an endemic plant in the African-Mediterranean countries, namely Algeria, Tunisia, and Morocco [2,20]. This plant is used by local populations in traditional medicine to treat numerous diseases and is also commonly used as a skin powder in traditional bathrooms [2,20-23]. O. glandulosum is also used in culinary preparations, as a food additive, in the breeding of bees, as a powerful disinfectant, and as an ingredient in perfumes [22,24]. O. glandulosum is rich in essential oils that have antibacterial, antifungal, insecticidal, antioxidant, antithrombin, antimutagenic, angiogenic, antiparasitic, and antihyperglycemic properties $[20,24,25]$. In the literature, thymol, carvacrol, $\gamma$-terpinene, and $p$-cymene are reported as the main components $[2,24]$. These chemicals have received increasing interest, particularly carvacrol, due to their many biological activities, including antibacterial and antifungal activities, antispasmodic effects, acetylcholine esterase inhibition, lipid peroxidase inhibition, radical scavenging effect, and cardiac depressant activity [24].

Lavandula dentata $\mathrm{L}$. grows indigenously on the mountainous regions bordering the Mediterranean with a temperate and mild climate, whose soils are poor and rocky, and is also wildly common on some islands in the Atlantic and in northern Africa, the Middle East, Arabia, and India [18]. It is cultivated for its aromatic flowers. Various ethnobotanical investigations are in favor of their use in therapy for the treatment of digestive disorders, such as inflammatory liver and intestinal diseases, but also for other inflammatory disorders [26-28]. The plant is also employed in cosmetics, as scent to perfume linen, in the laundry and soap industry, as well as a wound disinfectant $[18,27,28]$. Recent pharmacological studies relating to the essential oils of $L$. dentata have revealed a broad spectrum of biological activities [18,28].

The aim of this study was to assess in vitro the antibacterial activity of the essential oils of $O$. glandulosum and L. dentata against multidrug-resistant K. pneumoniae strains. The chemical composition of essential oils and their effect on the ultrastructure of the tested bacteria and on the release of cellular components that absorb at $260 \mathrm{~nm}$ were studied. Furthermore, the cytotoxicity and the production of ROS in human lymphocytes treated with essential oils were evaluated.

\section{Materials and Methods}

\subsection{Plant Material and Essential Oils Extraction}

Lavandula dentata L. and Origanum glandulosum Desf. were collected in Madegh forest (Oran, Algeria) in March 2016, carefully cleaned, and left to dry in the shade. The essential 
oils were obtained by steam distillation using a Clevenger type apparatus on $200 \mathrm{~g}$ (dry weight) of plant material for $3 \mathrm{~h}$. The resulting oils were dehydrated with magnesium sulfate $\left(\mathrm{MgSO}_{4}\right)$ and stored at $4{ }^{\circ} \mathrm{C}$ in the dark [29].

The essential oil yield, the ratio of the weight of the extracted oil to the dry weight of the plant, was calculated according to the formula by Cheurfa et al. [30].

\subsection{Bacterial Strains}

Fifteen extended-spectrum beta-lactamase (ESBL) Klebsiella pneumoniae strains were isolated in different medical specimens (urine, pus, blood culture, cerebrospinal fluid, catheter, peritoneal abscess, surgical wound) from the various departments of the Regional Military University Hospital of Oran, Algeria. Different clinical specimens including blood, cerebrospinal fluids, urine and catheter, pus, perirectal abscess, and surgical wounds were collected from patients with suspected clinical infections in different units and departments of the hospital. The specimens were cultured on blood, MacConkey, and CLED agar (for urine only) plates and incubated aerobically for $24 \mathrm{~h}$ at $37^{\circ} \mathrm{C}$ for preliminary identification of bacteria using conventional colony morphology, Gram stain reaction, and disc diffusion test for antibiotic susceptibility testing (AST). Confirmation of isolates, antibiogram, minimum inhibitory concentration (MIC), and detection of resistance phenotypes were carried out using the automated Vitek 2 (BioMérieux) identification and susceptibility method. ES $\beta L$ production was confirmed by the synergy and combination disc tests. ES $\beta$ L genes were detected by conventional simplex PCR. A total of 630 clinical samples of patients (one sample per patient) were processed. Klebsiella pneumoniae was isolated in $40(6.3 \%)$ samples, and 15 of these (37.5\%) produced ES $\beta \mathrm{L}$. In the disc diffusion AST assay, all $40 \mathrm{~K}$. pneumoniae isolates were resistant to ampicillin and ticarcillin while all 40 isolates were sensitive to cefoxitin, imipenem, and ertapenem.

Group 1 blaCTX-M genes were detected in 13 of the 15 (86.7\%) KP-ES $\beta \mathrm{L}$ isolates, and $46.7 \%$ of these isolates were moderate biofilm producers.

The strains were kept in storage media and cultured in Mueller-Hinton broth at $37^{\circ} \mathrm{C}$ for 18-24 h before the test. Klebsiella pneumoniae ATCC (700603) was used as control.

\subsection{Antibacterial Activity Test}

\subsubsection{Disc Diffusion Assay}

The activity of the oil was assessed by the agar diffusion technique. Briefly, a strain culture of 18-24 h on Mueller-Hinton broth was prepared at a concentration of $10^{8} \mathrm{CFU} / \mathrm{mL}$ and then seeded on Mueller-Hinton agar (Fluka BioChemika, Madrid, Spain) by swabbing according to the recommendations of The Clinical and Laboratory Standards Institute guidelines (CLSI 2014). A sterile paper disc (6 mm diameter) imbibed with $10 \mu \mathrm{L}$ of the tested oil was placed in the center of the seeded dish [31,32] and the plates were then stored for $1 \mathrm{~h}$ at room temperature.

After $24 \mathrm{~h}$ of incubation at $37^{\circ} \mathrm{C}$, the inhibition zones were measured (mm). All experiments were performed in triplicate. The susceptibility of bacterial strains to the essential oil was classified as follows: not susceptible for a diameter of lesser than $8 \mathrm{~mm}$, moderately susceptible $(+)$ for a diameter ranging from 8 to $14 \mathrm{~mm}$, susceptible $(++)$ for a diameter of 14 to $20 \mathrm{~mm}$, and very susceptible (+++) for a diameter greater than $20 \mathrm{~mm}$ [1].

\subsubsection{Determination of MIC and MBC}

After growing on Mueller-Hinton (MH) agar plates, bacterial strains were suspended in $\mathrm{MH}$ broth. The minimum inhibitory concentration MIC values were determined using MH broth dilution method according to Khadir et al. [32] and Bazargani et al. [33] with some modifications.

The inoculum suspensions were prepared from $6 \mathrm{~h}$ broth cultures (diluted to $1 / 100$ ) and adjusted to a 0.5 McFarland standard turbidity. The essential oil extracts, sterilized by $0.45 \mathrm{~mm}$ Millipore filters, were added to $\mathrm{MH}$ broth medium. Serial 10-fold dilutions 
were made in the MH broth and 1\% of Tween 80 (Fluka Bio Chemika, Spain) was added to ensure the miscibility of the oils.

Final oil concentrations ranged between 50 and $0.098 \mathrm{mg} / \mathrm{mL}$ for $O$. glandulosum and 100 and $0.19 \mathrm{mg} / \mathrm{mL}$ for L. dentata, following 2-fold dilution. A positive control consisting of $100 \mu \mathrm{L}$ of bacterial suspension in $\mathrm{MH}$ and a negative control consisting of MH broth with Tween 80 at $1 \%$ were used. After testing concentrations diluted tenfold, the lowest concentration that had shown inhibitory activity was subjected to further twofold dilution for more precise measurement of MIC. The bacterial suspensions were aerobically incubated for $24 \mathrm{~h}$ at $37^{\circ} \mathrm{C}$. The MIC was defined as the lowest concentration able to inhibit any visible bacterial growth.

To determine the minimum bactericidal concentration (MBC), a $10 \mu \mathrm{L}$ aliquot from each tube showing no visible growth was distributed into plates of MHA. MBC was the lowest concentration which did not give culture on the agar plates after $24 \mathrm{~h}$ at $37^{\circ} \mathrm{C}$.

\subsection{Gas Chromatography/Mass Spectrometry (GC/MS) Analysis}

As reported in Flamini et al. [34], gas chromatography/mass spectrometry (GC/MS) analyses were performed with a Varian CP-3800 instrument (Agilent Technologies Inc., Santa Clara, CA, USA) using a non-polar DB-5 (Agilent Technologies Inc., Santa Clara, CA, USA) capillary column (length: $30 \mathrm{~m}$; internal diameter $0.25 \mathrm{~mm}$; film thickness $0.25 \mu \mathrm{m}$ ) and a ion trap mass detector Varian Saturn 2000 (Agilent Technologies Inc., Santa Clara, CA, USA, with the following temperature program: from 60 to $240{ }^{\circ} \mathrm{C}$ at $3{ }^{\circ} \mathrm{C} / \mathrm{min}$, injector and transfer line temperature 220 and $240{ }^{\circ} \mathrm{C}$, respectively. The carrier gas was He at $1 \mathrm{~mL} / \mathrm{min}$ and the injection volume $1 \mu \mathrm{L}$.

The identification of the constituents was based on the comparison of their retention times (Rt) with those of the pure reference samples and their linear retention indices (LRI) determined using the $t R$ of a series of $n$-alkanes. The detected mass spectra were compared to those listed in the NIST (National Institute of Standards \& Technology) and ADAMS commercial libraries, as well as in a homemade mass spectra library.

\subsection{Measurement of Release of 260-nm Absorbing Cellular Materials}

Measurement of the release of cellular materials absorbing at $260 \mathrm{~nm}$ from K. pneumoniae ESBL cells was performed in $2 \mathrm{~mL}$ aliquots of the bacterial inocula, which were diluted in MHB to obtain $1 \times 10^{6} \mathrm{CFU} / \mathrm{mL}$. Then, $1 \mathrm{~mL}$ of the suspensions were incubated with the essential oils at the MIC at $37^{\circ} \mathrm{C}$ for $60 \mathrm{~min}$, then filtered through filter membranes $(0.22 \mu \mathrm{m})$ and the absorbance of the filtrates was measured at $260 \mathrm{~nm}$ using a Thermo Helios Omega UV-Vis spectrophotometer. Bacterial suspensions without essential oils were used as controls and similarly tested [35].

\subsection{Transmission Electron Microscopy TEM}

Bacterial suspensions $\left(5 \mathrm{~mL}\right.$ ) at $1 \times 10^{7} \mathrm{CFU} / \mathrm{mL}$ were incubated (at $37^{\circ} \mathrm{C}$ for $24 \mathrm{~h}$ ) without (negative control) and with the essential oils of the most active plant, O. glandulosum, at concentration corresponding to the MIC value. After incubation, the bacterial suspensions were centrifuged at $1300 \mathrm{~g}$ for $10 \mathrm{~min}$ at room temperature and the pellets underwent fixation in $2.5 \%$ glutaraldehyde buffered solution for $2 \mathrm{~h}$ at room temperature and post-fixation in $1 \%$ osmium tetroxide buffered solution for $1.5 \mathrm{~h}$ at room temperature. The specimens then underwent dehydration with ethyl alcohol and embedding in Spurr resin. Sections $50 \mathrm{~nm}$ thick were stained with uranyl acetate replacement (UAR) dye (Electron Microscopy Sciences) and lead citrate. Observations were carried out under a Philips EM 208S TEM at 80 KV.

\subsection{Blood Collection and Polymorphonuclear Leukocytes (PMN) Isolation}

The blood was collected from three healthy fasting donors subjected to peripheral blood sampling in $\mathrm{K}_{3}$ EDTA vacutainers (Becton Dickinson, Plymouth, UK). PMN isolation was performed following the protocol reported by Russi et al. [36] and Di Napoli et al. [37]. 
In summary, PMNs were isolated using a discontinuous gradient. The blood was centrifuged at $200 \times g$ for $25 \mathrm{~min}$ at room temperature. The PMN layer was collected and washed twice in PBS.

\subsection{Cell Viability Test}

In order to study the safety of the essential oils, their cytotoxicity was evaluated by the MTT test on human lymphocytes, which were purified by Ficoll-Paque density gradient centrifugation [38,39]. Briefly, $432.9 \mu \mathrm{L}$ of RPMI1640 medium $\left(1 \times 10^{6}\right.$ lymphocytes $\left./ \mathrm{mL}\right)$ were treated with $20.3,40.6$, and $81.2 \mathrm{mg} / \mathrm{mL}$ of $L$. dentata and $2.6,5.2$, and $10.4 \mathrm{mg} / \mathrm{mL}$ of $O$. glandulosum essential oils and incubated at $24-37^{\circ} \mathrm{C}$ and $5 \% \mathrm{CO}_{2}$. The three concentrations correspond to the mean MIC value, half the mean MIC value, and double the mean MIC value.

3-(4,5-Dimethyllthiazol-2yl)-2,5-diphenyltetrazoliumbromide (MTT) was prepared according to the manufacturer's instructions (MTT Cell Viability assay Kit; Biotum, Inc.) and $40 \mu \mathrm{L}$ of a $5 \mathrm{mg} / \mathrm{mL}$ MTT solution was added and incubated for $2 \mathrm{~h}$ at $37^{\circ} \mathrm{C}$. The produced water-insoluble blue formazan crystals were dissolved in $500 \mu \mathrm{L}$ of dimethyl sulfoxide (DMSO; Sigma-Aldrich, Saint Quentin Fallavier, France) by shaking for $15 \mathrm{~min}$ using an orbital shaker at $20{ }^{\circ} \mathrm{C}$ [40]. Absorbance was measured at 570 and $630 \mathrm{~nm}$ to obtain the cell viability percentage, calculated using the following formula: $\operatorname{OD}(570 \mathrm{~nm})$ - OD $(630 \mathrm{~nm})$ treated $) /(\mathrm{OD}(570 \mathrm{~nm})-\mathrm{OD}(630 \mathrm{~nm})$ untreated $) \times 100 \%[17,41]$.

All experiments were performed in triplicate, and the relative cell viability was expressed as a percentage relative to the untreated control cells (cells in RPMI 1640 medium).

\subsection{Reactive Oxygen Species ROS Generation}

Dichlorofluorescein (DCF) assay was performed to quantify ROS generation according to Manna et al. [42]. The leukocytes were treated with essential oils (MIC values and double MIC values: Origanum 5.2 and $10.4 \mathrm{mg} / \mathrm{mL}$ and Lavandula 40.6 and $81.2 \mathrm{mg} / \mathrm{mL}$ ) for $6 \mathrm{~h}$ and then incubated with the non-polar and non-fluorescent $2^{\prime}, 7^{\prime}$-dichlorodihydrofluorescin diacetate (DCFH-DA), at $10 \mu \mathrm{M}$ as final concentration, for $15 \mathrm{~min}$ at $37^{\circ} \mathrm{C}$. ROS quantity was monitored by fluorescence (excitation wavelength of $350 \mathrm{~nm}$ and an emission wavelength of $600 \mathrm{~nm}$ ) on a microplate reader. Results were expressed as fluorescence intensity.

\subsection{Statistical Analysis}

The absorption at $260 \mathrm{~nm}$, the ROS generation, and the cell viability of human lymphocytes were examined by one-way analysis of variance (ANOVA), followed by Tukey's multiple comparison post hoc test. GraphPad Prism 5 was utilized for statistical analysis.

\section{Results}

\subsection{Essential Oils Extraction}

The average essential oil yields for $L$. dentata and $O$. glandulosum samples are $1.2 \%$ and $3.15 \%$ respectively.

\subsection{Gas Chromatography/Mass Spectrometry (GC/MS) Analysis}

The results of GC/MS chemical analyses of the essential oils are shown in Table 1.

In L. dentata essential oil, 43 components were identified by GC/MS. The main constituents are $\beta$-pinene (17.3\%), followed by myrtenal (10.2\%), trans-pinocarveol $(8.7 \%)$, $\alpha$-thujene (7.2\%), linalool (6.8\%), and 1.8-cineole (6.1\%). Among the identified 23 components, the analysis of $O$. glandulosum essential oil revealed that the main compounds are thymol (33.2\%), $\gamma$-terpinene (25.4\%), p-cymene (16.1\%), and carvacrol (13.0\%) (Table 1). 
Table 1. Chemical composition of the essential oils from O. glandulosum and L. dentata.

\begin{tabular}{|c|c|c|c|}
\hline Constituents & LRI & 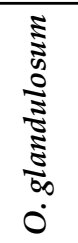 & 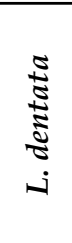 \\
\hline$\alpha$-thujene & 933 & 0.9 & 7.2 \\
\hline$\alpha$-pinene & 941 & 0.6 & \\
\hline camphene & 955 & & 1.0 \\
\hline thuja-2,4(10)-diene & 959 & & 0.4 \\
\hline 1-octen-3-ol & 981 & 0.3 & \\
\hline$\beta$-pinene & 982 & 0.2 & 17.3 \\
\hline 3-octanone & 987 & 0.2 & \\
\hline myrcene & 992 & 1.4 & \\
\hline$\alpha$-phellandrene & 1006 & 0.2 & \\
\hline$\alpha$-terpinene & 1020 & 2.9 & \\
\hline p-cymene & 1028 & 16.1 & 1.1 \\
\hline limonene & 1032 & 0.5 & 5.1 \\
\hline 1,8-cineole & 1034 & & 6.1 \\
\hline$\gamma$-terpinene & 1063 & 25.4 & \\
\hline cis-linalool oxide (furanoid) & 1076 & & 0.3 \\
\hline terpinolene & 1090 & & 0.8 \\
\hline linalool & 1101 & 0.6 & 6.8 \\
\hline hotrienol & 1103 & & 0.2 \\
\hline endo-fenchol & 1112 & & 0.2 \\
\hline cis- $p$-menth-2-en-1-ol & 1123 & & 0.6 \\
\hline$\alpha$-campholenal & 1125 & & 1.2 \\
\hline trans-pinocarveol & 1141 & & 8.7 \\
\hline cis-verbenol & 1142 & & 0.4 \\
\hline trans-verbenol & 1143 & & 2.2 \\
\hline pinocarvone & 1164 & & 4.1 \\
\hline Borneol & 1167 & 0.1 & 1.7 \\
\hline$p$-mentha-1,5-dien-8-ol & 1168 & & 0.5 \\
\hline 4-terpineol & 1179 & 0.6 & 0.9 \\
\hline cryptone & 1185 & & 3.6 \\
\hline$\alpha$-terpineol & 1191 & 0.4 & 1.0 \\
\hline myrtenal & 1194 & & 10.2 \\
\hline Verbenone & 1207 & & 0.3 \\
\hline trans-carveol & 1220 & & 1.1 \\
\hline methyl thymol & 1234 & 0.1 & \\
\hline cuminaldehyde & 1241 & & 3.9 \\
\hline
\end{tabular}


Table 1. Cont.

\begin{tabular}{|c|c|c|c|}
\hline Constituents & LRI & 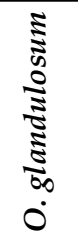 & 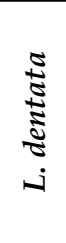 \\
\hline carvone & 1244 & & 1.6 \\
\hline methylcarvacrol & 1245 & 0.2 & \\
\hline piperitone & 1254 & & 0.6 \\
\hline phellandral & 1272 & & 0.8 \\
\hline bornylacetate & 1287 & & \\
\hline p-cymen-7-ol (syn. cumin alcohol) & 1290 & & 0.7 \\
\hline thymol & 1291 & 33.1 & \\
\hline p-mentha-1,8-dien-7-ol (syn. perilla alcohol) & 1297 & & 0.5 \\
\hline carvacrol & 1299 & 13.0 & \\
\hline (E)-3-hexenyl (E)-2-methylbut-2-enoate & 1325 & & 0.4 \\
\hline$\beta$-caryophyllene & 1419 & 1.5 & 0.2 \\
\hline$\beta$-selinene & 1487 & & 1.1 \\
\hline$\beta$-bisabolene & 1508 & 0.2 & \\
\hline trans- $\gamma$-cadinene & 1514 & & 0.2 \\
\hline trans-calamenene & 1523 & & 0.5 \\
\hline$\beta$-sesquiphellandrene & 1525 & 1.2 & \\
\hline caryophyllene oxide & 1582 & 0.2 & 0.4 \\
\hline$\beta$-eudesmol & 1650 & & 1.6 \\
\hline$\alpha$-bisabolol oxide B & 1654 & & 0.5 \\
\hline cadalene & 1673 & & 0.4 \\
\hline$\alpha$-bisabolol & 1686 & & 0.2 \\
\hline cis-14-nor-muurol-5-en-4-one & 1687 & & 1.5 \\
\hline monoterpene hydrocarbons & & 48.2 & 32.9 \\
\hline oxygenated monoterpenes & & 48.1 & 54.6 \\
\hline sesquiterpene hydrocarbons & & 2.9 & 2.4 \\
\hline oxygenated sesquiterpenes & & 0.2 & 4.2 \\
\hline Diterpenes & & 0.0 & 0.0 \\
\hline non-terpene derivatives & & 0.5 & 4.0 \\
\hline Total identified & & 99.9 & 98.1 \\
\hline
\end{tabular}

LRI: retention index on a HP-5 MS column.

\subsection{Antibacterial Activity}

The diameters of the inhibition zones caused by application of the essential oils on $\beta$-lactamase expanded spectrum producing K. pneumoniae are summarized in Table 2.

The essential oils extracted from $L$. dentata exert a growth inhibiting activity against ESBL K. pneumoniae strains with an average inhibiting zone of $9.3 \pm 0.9 \mathrm{~mm}$. The inhibition zone diameters observed with $O$. glandulosum show remarkable sensitivity of the tested bacteria with an average of $43.5 \pm 6.7 \mathrm{~mm}$ (Figure 1). 
O. glandulosum essential oils were found to be the most active with mean MIC and MBC values equal to 5.2 and $7.4 \mathrm{mg} / \mathrm{mL}$ followed by L. dentata with mean MIC and MBC values equal to 40.6 and $48.1 \mathrm{mg} / \mathrm{mL}$, respectively (Table 2).

Table 2. The table shows the inhibition haloes, expressed as $\mathrm{mm}$, and MIC and MBC values, expresses as $\mathrm{mg} / \mathrm{mL}$, obtained with $O$. glandulosum and L. dentata essential oils tested against ESBL $K$. pneumoniae strains.

\begin{tabular}{cccccc}
\hline \multicolumn{3}{c}{ O. glandulosum } & & \multicolumn{2}{c}{ L. dentata } \\
\hline Inhibition Zone & MIC & MBC & Inhibition Zone & MIC & MBC \\
\hline $43.5 \pm 6.7$ & $5.2 \pm 3.3$ & $7.4 \pm 5.1$ & $9.3 \pm 0.9$ & $40.6 \pm 25.5$ & $48.1 \pm 25.7$ \\
\hline
\end{tabular}

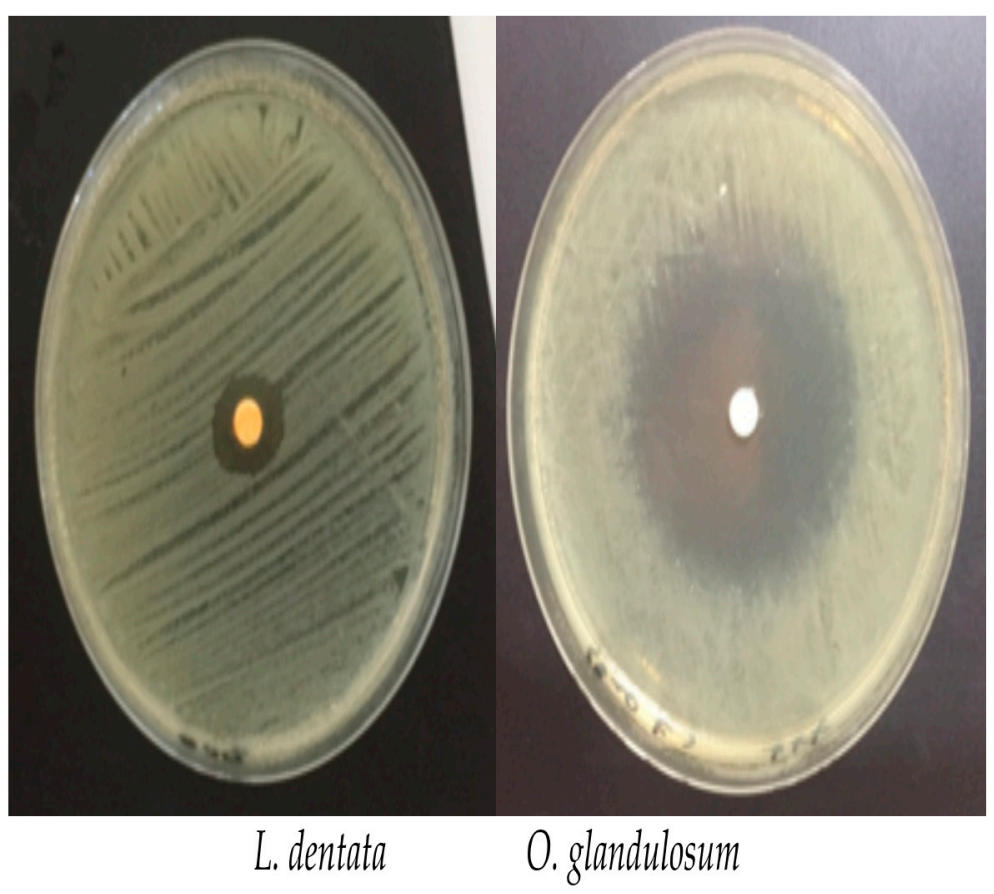

Figure 1. Inhibition halo of the L. dentata and O. glandulosum on activity against specific ESBL $K$. pneumoniae strains, by disc diffusion method observed at the MIC values.

The essential oils of $O$. glandulosum were found to be more active than the essential oils of $L$. dentata. In fact, O. glandulosum essential oils have mean MIC and MBC values equal to 5.2 and $7.4 \mathrm{mg} / \mathrm{mL}$, while $L$. dentata have mean MIC and MBC values equal to 40.6 and $48.1 \mathrm{mg} / \mathrm{mL}$ respectively (Table 2 ).

\subsection{Measurement of Release of $260 \mathrm{~nm}$ Absorbing Cellular Materials}

In this study, the absorption at $260 \mathrm{~nm}$ of the treated and untreated filtrates was significantly different. Table 3 shows the absorbent materials at $260 \mathrm{~nm}$ in the treated $K$. pneumoniae filtrates. Significant increases in absorption at $260 \mathrm{~nm}$ occurred after treatment with the essential oils of $L$. dentata and O. glandulosum at the MIC values. The treated filtrates gave an absorbance of 1.417 for O. glandulosum and 1.342 for L. dentata. Control untreated filtrates showed an absorbance of 0.003 and 0.002 (Table 3).

\subsection{TEM (Transmission Electron Microscopy) Observation}

Under TEM microscope, untreated samples appeared as typically rod-shaped cells (Figure 2a,b), delimited by a well visible, typically smooth, and multi-layered surface (Figure $2 b, c)$. The protoplast has a normal grainy appearance, more electron-dense in the periphery and more clear in the center (Figure 2b,c). Differently, oregano and lavender 
essential oil-treated cells lost the typical rod shape and appear globular (Figure $2 \mathrm{~d}-\mathrm{f}$ ). The protoplast is not grainy but shows large electron dense areas (Figure $2 \mathrm{~d}-\mathrm{f}$ ). The cell surface developed bulges and external curly filaments (Figure $2 \mathrm{~d}-\mathrm{f}$ ). At higher magnification, the bulges can appear as dilation of the outer membrane, while the inner one and the wall maintain their continuity (arrow in Figure 2e).

Table 3. Effect of essential oils from L. dentata and O. glandulosum, tested at MIC values $(40.6 \mathrm{mg} / \mathrm{mL}$ of L. dentata EO; $5.2 \mathrm{mg} / \mathrm{mL}$ of $O$. glandulosum EO) on the release of the $260 \mathrm{~nm}$ absorbent material from ESBL K. pneumoniae. Lower case letters denote significant difference at $p<0.05$ between samples.

\begin{tabular}{cc}
\hline \multicolumn{2}{c}{ Absorbance (260 $\mathbf{~ m})$} \\
\hline Control & $0.003 \pm 0.001 \mathrm{a}$ \\
\hline O. glandulosum & $1.466 \pm 0.048 \mathrm{~b}$ \\
\hline L. dentata & $1.345 \pm 0.048 \mathrm{c}$ \\
\hline
\end{tabular}

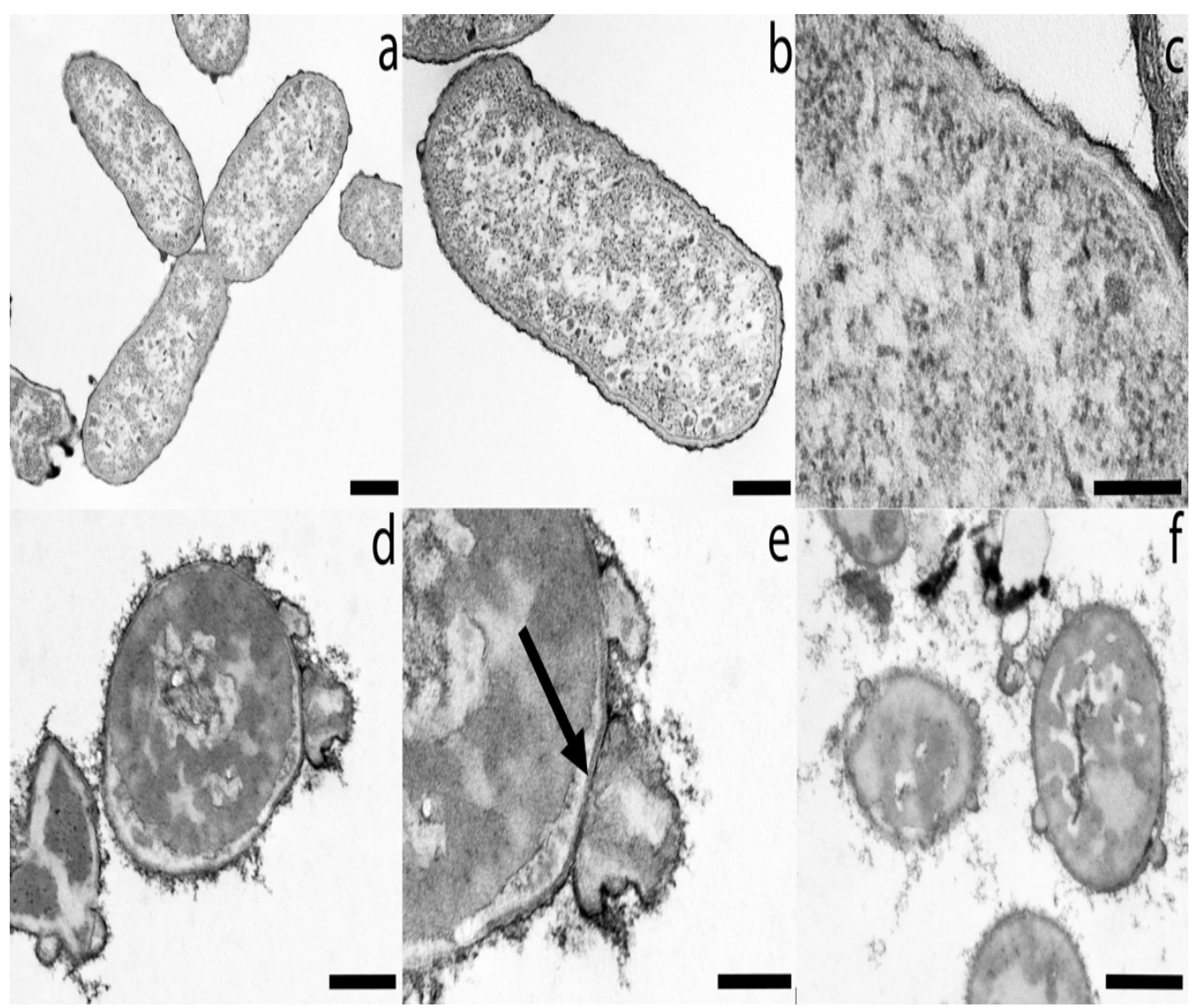

Figure 2. The figure shows TEM micrographs of untreated $K$. pneumoniae samples (a-c) and $K$. pneumoniae treated with O. glandulosum (d,e) and L. dentata (f) essential oil at the mean MIC value. (a) Three typical rod-shaped cells. Those lined up are still dividing. (b) A bacterial cell taken at higher magnification shows the grainy protoplast delimited by a smooth external cell wall. (c) Detail of a bacterial cell shows the grainy protoplast and the multi-layered surface, taken at higher magnification. (d) A O. glandulosum essential oil-treated bacterial cell with a globular-shape appearance. The protoplast, not grainy, is electron dense in large areas. The surface developed large bulges and an external hairy material. (e) Details of the altered cell taken at higher magnification. The arrow shows the continuity of the inner membrane and the cell wall. (f) Bacterial cells treated with L. dentata essential oil. The protoplast, with no grainy appearance, appears moderately dense in large areas. Scale bars: $500 \mathrm{~nm}(\mathbf{a}, \mathbf{f}) ; 300 \mathrm{~nm}(\mathbf{b}, \mathbf{d}) ; 200 \mathrm{~nm}(\mathbf{c}, \mathbf{e})$. 


\subsection{Cell Viability Test}

Both the essential oils exhibited a good safety profile against lymphocytes after a $24 \mathrm{~h}$ incubation (Figure 3). Lavender and oregano essential oils showed only mild cytotoxic effects and no reduction in cell viability was observed at all tested concentrations.

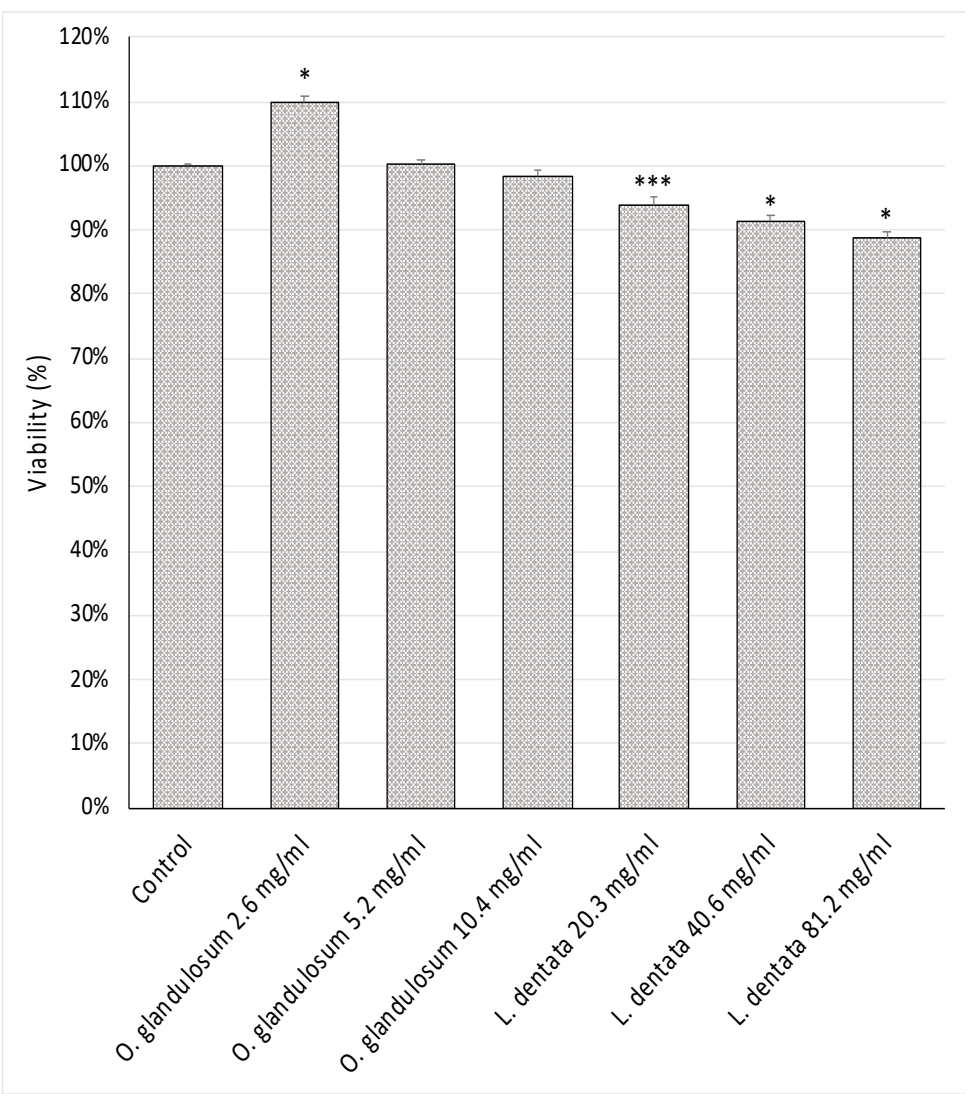

Figure 3. Effect of essential oils of L. dentata and O. glandulosum on the cell viability of human lymphocytes (MTT test): viability (\%) of human lymphocytes $\left(1 \times 10^{6}\right.$ cells $\left./ \mathrm{mL}\right)$ incubated with medium alone (control), Origanum (2.6, 5.2, and $10.4 \mathrm{mg} / \mathrm{mL}$ ) and Lavandula $(20.3,40.6$, and $81.2 \mathrm{mg} / \mathrm{mL}$ ) for $24 \mathrm{~h}$. Statistical analysis was performed by one-way ANOVA followed by Tukey's test $\left(^{*} p<0.05\right.$; *** $p<0.001)$.

\subsection{Reactive Oxygen Species (ROS) Generation}

As can be seen from Figure 4, ROS production in PMNs decreases when treated with $O$. glandulosum and L. dentata extracts compared to the control. Notably, ROS levels decrease when leukocytes have been treated with double MIC concentrations for both essential oil extracts. In particular, the extract of $O$. glandulosum is more active than that of L. dentata. 


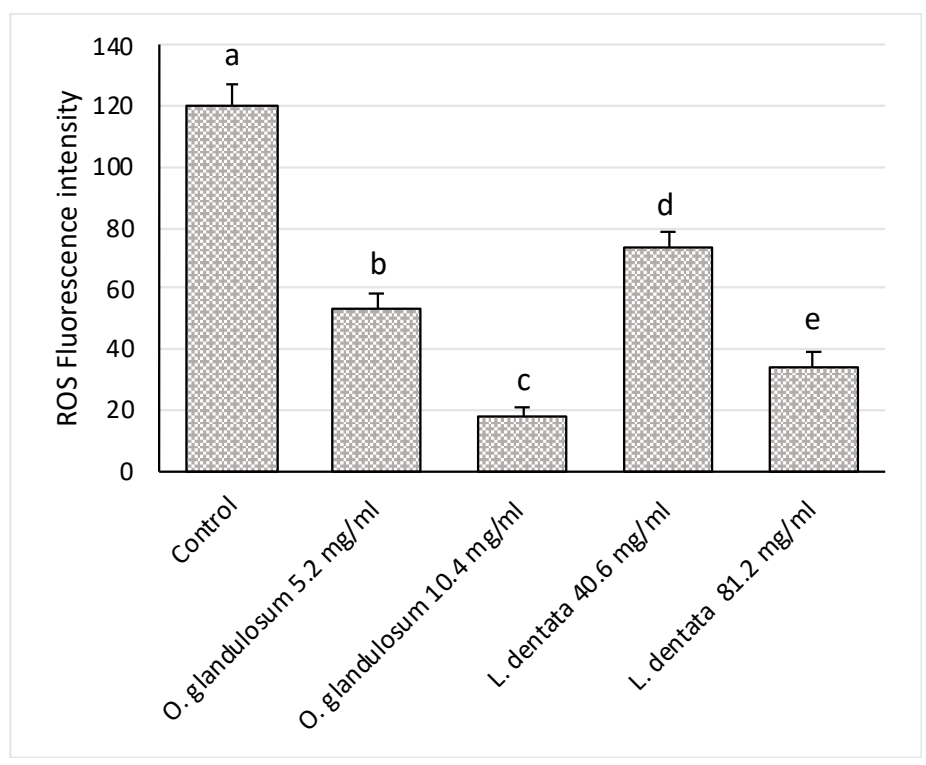

Figure 4. Effect of essential oil extracts (O. glandulosum 5.2 and $10.4 \mathrm{mg} / \mathrm{mL}$ and L. dentata 40.6 and $81.2 \mathrm{mg} / \mathrm{mL}$ ) on ROS production in polymorphonuclear neutrophils (PMN). Data were presented as mean and standard error and were analyzed with a paired $t$-test. Bars not accompanied by the same letter were significantly different at $p<0.05$.

\section{Discussion}

The results of this work show that both L. dentata and O. glandulosum are valid sources of essential oils with useful biological activities, and oregano essential oil in particular proved to be most active for the tested activities.

For L. dentata, our essential oil yields are in agreement with the literature data: $1.44 \%$ [43], $0.89 \%$ [18], and 1.1\% [44]. Higher yields than ours were found by Bachiri et al. [28], Bachiri et al. [27], and Dammak et al. [45]: 2.9\%, 2.6\%, and 1.76\% respectively. Conversely, Dob et al. [46] and Silva-Flores et al. [47] reported yield results lower than ours: $0.79 \%$ and $0.53 \%$ respectively. As for O. glandulosum, our essential oil yields are comparable to those obtained with the same species by Belhattab et al. [23], while Bekhechi et al. [22] and Bendahou et al. [21] found yields higher than ours. These differences in the yields of essential oils are not surprising and may be related to different conditions and factors, namely the species, genotype, environment, harvest period, place of drying, and geographical origin of the plant $[27,28]$.

Among the identified 23 components, analysis of $O$. glandulosum essential oil revealed that the main compounds were thymol (33.2\%), $\gamma$-terpinene (25.4\%), p-cymene $(16.1 \%)$, and carvacrol (13.0\%) (Table 1).

As for the chemical composition, the percentage of 1,8-cineole (6.1\%) in the oil of $L$. dentata revealed a dissimilarity with those described in the literature. Dob et al. [46] reported that the main constituents of the oil were 1,8-cineole (38.4\%), cis-verbenol (4.3\%), $p$-cymen8 -ol $(3.8 \%)$, and fenchone (2.3\%). Ouedrhiri et al. [44] found that the two monoterpenes $\beta$-pinene (25.82\%) and 1,8-cineole (10.82\%) were the main essential oil compounds of L. dentata. Dammak et al. [45] showed that the main component was 1,8-cineole. SilvaFlores et al. [47] identified 16 components, with oxygenated monoterpenes $(80.71 \%)$ as main constituents followed by monoterpene hydrocarbons $(16.19 \%)$; within these chemical classes, the main constituents were 1,8-cineole (68.59\%) and $\beta$-pinene $(11.53 \%)$, respectively.

As for the chemical composition of O. glandulosum essential oil, the results of this work are comparable to some literature data on the same species [21,25,32], but different results have also been obtained by Belhattab et al. [23], who found that the major compounds in O. glandulosum were carvacrol (47.0\%), $\gamma$-terpinene (13.4\%), $p$-Cymene $(11.2 \%)$, and thymol (6.6\%). Nabet et al. [48] also found that the main compounds were $\gamma$-terpinene $(29.4 \%)$ and carvacrol (12.9\%). Nabti et al. [2] found that the 4 main components detected in plants 
from different Algeria regions were thymol (15.1-56.3\%), carvacrol (2.8-59.6\%), $\gamma$-terpinene (9.8-21.8\%), and $p$-cymene (8.5-13.9\%).

Considering the availability of $O$. glandolosum in Algeria and their richness in essential oil as well as the homogeneity and the stability of the chemical composition of its essential oil, this plant is likely to have an industrial interest and can also be recommended as a potential source of thymol [22].

The previously reported differences in the chemical composition, in particular in the quantity of the main components of the essential oils, may be due to variations in many factors such as climate, thermal range, duration of sunshine, collection period, type of soil, and the considered organs of the plant $[2,18,27]$. These chemical differences may also affect their biological activities [27,49]. Hence, the composition of the essential oils has been the subject of several studies, from which it can be concluded that the plants exhibit chemical variability.

Nikolić et al. [50] and Dammak et al. [45] reported that the biological activities of the essential oils depend on their chemical composition.

It is noteworthy that the tested essential oils show remarkable antibacterial activity against antibiotic-resistant bacterial strains.

As for O. glandulosum, which is the more active, our antibacterial results are in agreement with those reported by Bendahou et al. [21], who noted in their study that the $O$. glandulosum essential oils exhibited an antimicrobial activity against 10 Gram-negative bacteria. Simlarly Bekhechi et al. [22] noted that $O$. glandulosum essential oils were very active against the Gram-negative and Gram-positive strains tested (P. aeruginosa, K. pneumoniae, Enterobacter cloacae, Salmonella typhi, Proteus mirabilis, E. coli, Citrobacter freundii; Listeria monocytogenes, and Staphylococcus aureus) some of which also ATCC. Among these K. pneumoniae, both obtained from clinical isolates and the ATCC strain, was inhibited by the essential oil of oregano, while P. aeruginosa was resistant, as often happens for this bacterium. Nabti et al. [2] also reported that the essential oils from O. glandulosum showed good antibacterial activity against uropathogenic multiresistant strains of $E$. coli, while Bendahou, et al. [21] and Bekhechi et al. [22] reported that the essential oil of oregano was active precisely on K. pneumoniae as our data also showed. The antimicrobial activity of $O$. glandulosum essential oils was possibly related to its phenolic components, such as thymol, carvacrol, but also to their biosynthetic intermediates $p$-cymene and c-terpinene. It has been suggested that phenolic derivatives may cause membrane-disrupting activities [21]. In fact, Nabet et al. [48] reported that phenolic components and their precursors contained in essential oils are responsible for high antifungal activity.

Nabti et al. [2] found that carvacrol and thymol were the most active components and showed good antibacterial activity (MIC and MBC ranging from 0.25 to $0.5 \mathrm{mg} / \mathrm{mL}$ ), p-cymene was less active, and $\gamma$-terpinene was totally inactive against all the strains tested. There are reports in the literature that oregano essential oils have the ability to sensitize the cell membrane phospholipid bilayer, causing increased permeability and leakage of vital intracellular constituents or alteration of the enzyme systems in Gram-positive and Gram-negative bacteria [48,51].

Hernández-González et al. [52] in their study attributed the antimicrobial capacity of oregano essential oil to thymol and carvacrol, capable of disintegrating the outer membrane of the microorganism, causing cell death.

The results on $L$. dentata antibacterial activity are according to literature data on lavender species $[27,28,53]$. Yang et al. [54] found remarkable antibacterial activity in the essential oils of Lavandula angustifolia against multidrug-resistant (MDR) K. pneumoniae strains and also highlight the probable mechanism of action. In contrast, Mohamed and Eddine [43] found that $L$. dentata essential oils had very low antibacterial activity against antibiotic-resistant strains of K. pneumoniae, which was however evaluated only by the disc diffusion method. Our data do not agree with this last statement as we have obtained interesting MIC values. The antibacterial activity of Moroccan $L$. dentata essential oils 
is quite different from the Algerian oils and different results have been found in other studies [28].

The above reported differences in the antibacterial activity could be related to the bacterial species tested and the previously discussed differences in the chemical composition of the oils.

As for the ways of action of the essential oils on the bacterial cells, the antimicrobial activity could result from the joint association of several mechanisms on different cellular targets, like plasma membrane, cell wall, or bacterial DNA [27,54]. The oil could cross cell membranes, get inside the cell, and interact with critical intracellular sites for antibacterial activity. It has already been reported that monoterpenes act on both Gram-positive and Gram-negative bacteria, damaging their biomembranes and, in particular, disrupting the lipid fraction of the plasma membrane, impairing membrane permeability and causing leakage of intracellular materials [55]. Furthermore, literature data suggest that an antibacterial agent's ability to kill bacteria may be a function of the stable interaction complex between drug-related topoisomerase and cleaved DNA. On this basis, the effect of the antibacterial agent could also be the generation of double-stranded DNA breaks that are trapped by covalently bound topoisomerase. Consequently, the DNA replication machinery stops and that immediately leads to bacteriostasis and possibly to cell death [35]. Yang et al. [54] related the antibacterial effect of lavender against multidrug-resistant $K$. pneumoniae strains to different ways of action.

The TEM observations showed that essential oil treatments induced alterations in the typical appearance of the untreated cells. In fact, the essential oil-treated cells lost the typical rod shape and appear globular, suggesting a change to the cell wall, which maintains the correct shape of the cell. Literature data show damage to the bacterial cell wall under essential oil treatments. Rasooli et al. [56] observed severe effects of thyme essential oils on the Listeria cell wall, leading to a rupture of the wall which lost its smoothness and uniformity. Dutra et al. [51] showed disruption of the cell wall and deformation of the integrity of Alicyclobacillus spp. after treatment with Origanum vulgare essential oil.

The bulged appearance of treated cells are in agreement to Yang et al. [54], who found that multidrug-resistant K. pneumoniae upon exposure to lavender essential oil developed a corrugated envelope with irregularities, well evident under scanning electron microscopy (SEM). Yang et al. [54] also demonstrated disruption of bacterial membranes under essential oil treatments via oxidative stress. This is consistent with our observations of bulged surfaces under TEM. Our image showing protrusion of the outer membrane, which is damaged first, while the continuity of the cell wall and the inner membrane is still maintained, could represent a first step in the damage to the bacterial surface. In fact, lavender essential oil was found to modify the bacterial membrane permeability of MDR K. pneumoniae strains. Change in membrane permeability could easily lead to swelling phenomena, giving images of surface bulging like those we observed for the essential oil-treated samples, and when the disruption involves both membranes and the cell wall, leaking of cytoplasmic material occurs [54]. Loss of cell material is demonstrated by our findings of the increased release of $260 \mathrm{~nm}$ absorbent material from the bacterial cells after essential oil exposure. This also suggests that the essential oils caused significant and irreversible damage to the cytoplasmic membrane and disruption of permeability. This is also consistent with previous results showing similar data related to plant essential oils tested against bacterial strains $[35,52,57,58]$. Furthermore, the evaluation of the release of absorbent materials from the treated cells can suggest a way of action of essential oils against bacteria. In fact, an important characteristic of essential oils and their main components (carvacrol, terpenes, phenols, aldehydes, and ketones) is hydrophobicity, which allows them to accumulate in bacterial and fungal cell membranes, causing their disruption and consequent antibacterial activity [57-59]. It has already been reported that monoterpenes act on both Gram-positive and Gram-negative bacteria, damaging their biomembranes and, in particular, disrupting the lipid fraction of the plasma membrane, impairing membrane permeability and causing leakage of intracellular materials [55]. 
Damage to treated cells is also suggested by the appearance of the bacterial cytoplasm. In fact, the cytoplasm of the treated bacteria lost its typical grainy appearance and developed large moderately dense areas, which suggests cytoplasm degeneration. Furthermore, observations of the external curly filaments suggest development of an external capsule, which could be induced by the essential oil exposure. It was demonstrated in K. pneumoniae that the construction of a capsule is upregulated by antimicrobial peptides [60].

The safety of the tested substances has been evaluated by the cell viability test. It clearly showed that the essential oils tested did not have cytotoxicity activity against human lymphocytes under the used MTT test. Instead, O. glandulosum essential oils even activated the lymphocyte compared to the untreated ones.

In the case of cytotoxic compounds, this phenomenon can be interpreted as a rescue mechanism. At low subtoxic concentrations, cells escape detrimental stimuli by the induction of proliferation, while at higher concentrations, this defense mechanism is overridden by the cytotoxic effects [61].

The respiratory chain, other electron transport systems, and cell enzymes convert the MTT and other tetrazolium salts into formazan crystals. The quantity of these crystals can be determined by spectrophotometry and is used to estimate the number of mitochondria and, thus, the number of viable cells in the sample.

Our results are consistent with those in the literature, reporting no cytotoxicity on several cell lines treated with the essential oils of several plant species, such as Thymus zygis subsp. sylvestris [49], Aniba canelilla [62], and Salvia officinalis [63].

However, testing cytotoxicity is essential, especially in the case of substances with good profiles of biological activities. In fact, lemon myrtle oil has been shown to have significant antimicrobial activity against different organisms, but in vitro cytotoxicity tests indicated a very toxic effect against primary cell cultures of fibroblasts of human skin [49]. Sinha et al. [64] detected a reduction in viability of human lymphocytes treated with the essential oils of palmarosa, citronella, lemongrass, and vetiver, including loss of integrity of the plasma membrane associated with necrosis. Another study showed that lavender oil is cytotoxic in vitro on human skin cells (endothelial cells and fibroblasts) at a concentration of $0.25 \%(v / v)$ [65]. In addition, carvacrol is known to be toxic to mammalian cells at high concentrations; on the other hand, protective effects on DNA have been observed with carvacrol on mammalian cells cultured in vitro [49].

The excessive ROS production is deleterious for cells and tissues since they change the structure and function of biomolecules.

O. glandulosum and L. dentata extracts displayed inhibitory effects on leukocyte ROS production compared to untreated control cells. Thus, these extracts can act as antiinflammatory agents as may be efficient in protecting the organism from excess ROS production via radical scavenging activity.

The test of ROS generation confirms the activation of the lymphocytes under the essential oil treatments. The activity on lymphocytes is very interesting because these cells play a crucial role in the immune system. Hence, the essential oils, in addition to fighting bacterial infections, could also be able to activate the immune system.

It should be noted that a reduction in (excessive) ROS production can indeed reduce tissue damage/inflammation on one side, but that this may be at the expense of the antibacterial efficacy of the cells via ROS, but the strong direct effect of essential oils could compensate for this reduction.

Concluding, the in vitro results of the essential oils showed interesting activities. $O$. glandulosum and L. dentata show remarkable antibacterial and bactericidal activity against antibiotic-resistant K. pneumoniae strains, with no cytotoxicity on human lymphocytes. Instead, they could even potentiate the immune response. Thus, taking into account the interesting yield of the extraction from the selected plants and the increasing occurrence of antibiotic-resistant bacteria strains, they are suggested as potential candidate for antibacterial drugs, even though further studies are required to assess the bioavailability, the in vivo activities, and safety to finally confirm their potential application to human health. 
Author Contributions: Conceptualization, C.B. and S.M.; methodology, C.B., V.M., S.S., R.N. and M.S.B.; validation, C.B. and M.S.B.; formal analysis S.S., V.M., R.N., M.P., F.C. and G.F.; investigation, C.B. and M.S.B.; resources, V.M., M.P., A.B. and R.N.; data curation, A.Z., S.S. and V.M.; writingoriginal draft preparation, C.B., V.M., S.S., A.B., S.M. and M.S.B.; writing-review and editing, C.B., A.B. and M.S.B.; visualization, A.K., C.B. and S.M.; supervision, S.M.; project administration, S.M. All authors have read and agreed to the published version of the manuscript.

Funding: This research received no external funding.

Institutional Review Board Statement: This study did not involve humans or animals.

Informed Consent Statement: Written informed consent has been obtained from the patients to publish this paper.

Acknowledgments: We are grateful to the Department of Biology, Federico II University, Naples, Italy, and The Laboratory of Applied Microbiology in the Department of Biology, SNV, University of Oran1 Ahmed Ben Bella, Algeria.

Conflicts of Interest: The authors declare no conflict of interest.

\section{References}

1. Bertella, A.; Benlahcen, K.; Abouamama, S.; Pinto, D.C.; Maamar, K.; Kihal, M.; Silva, A.M.S. Artemisia herba-alba Asso. essential oil antibacterial activity and acute toxicity. Ind. Crop. Prod. 2018, 116, 137-143. [CrossRef]

2. Nabti, L.Z.; Sahli, F.; Laouar, H.; Olowo-Okere, A.; Wandjou, J.G.N.; Maggi, F. Chemical Composition and Antibacterial Activity of Essential Oils from the Algerian Endemic Origanum glandulosum Desf. against Multidrug-Resistant Uropathogenic E. coli Isolates. Antibiotics 2020, 9, 29. [CrossRef] [PubMed]

3. Khalifa, A.B.H.; Khedher, M. Epidémiologie des souches de Klebsiella spp. uropathogènes productrices de $\beta$-lactamases à spectre élargi dans un hôpital universitaire Tunisien, 2009. Pathol. Biol. 2012, 60, e1-e5. [CrossRef] [PubMed]

4. Wyres, K.L.; Holt, K.E. Klebsiella pneumoniae Population Genomics and Antimicrobial-Resistant Clones. Trends Microbiol. 2016, 24, 944-956. [CrossRef] [PubMed]

5. Markovska, R.; Stoeva, T.; Boyanova, L.; Stankova, P.; Pencheva, D.; Keuleyan, E.; Murjeva, M.; Sredkova, M.; Ivanova, D.; Lazarova, G.; et al. Dissemination of successful international clone ST15 and clonal complex 17 among Bulgarian CTX-M-15 producing K. pneumoniae isolates. Diagn. Microbiol. Infect. Dis. 2017, 89, 310-313. [CrossRef]

6. Panda, P.; Jhon, N.; Sao, S.; Information, P.E.K.F.C. Antibiogram, ESBL production and carbapenemase detection of Klebsiella spp. in hospital-acquired infection. Apollo Med. 2016, 13, 156-162. [CrossRef]

7. Akturk, H.; Sutcu, M.; Somer, A.; Aydın, D.; Cihan, R.; Ozdemir, A.; Coban, A.; Ince, Z.; Citak, A.; Salman, N. Carbapenemresistant Klebsiella pneumoniae colonization in pediatric and neonatal intensive care units: Risk factors for progression to infection. Braz. J. Infect. Dis. 2016, 20, 134-140. [CrossRef]

8. Cescutti, P.; De Benedetto, G.; Rizzo, R. Structural determination of the polysaccharide isolated from biofilms produced by a clinical strain of Klebsiella pneumoniae. Carbohydr. Res. 2016, 430, 29-35. [CrossRef]

9. Delatour, C.; Chalvon, N.; Prieur, N.; Mateu, P. A history of community-acquired hypervirulent Klebsiella pneumoniae severe sepsis. Anaesth. Crit. Care Pain Med. 2018, 37, 273-275. [CrossRef]

10. Hauser, N.; Tanner, E.; Keuroghlian, M.; Koduri, L. A case of Klebsiella oxytoca endocarditis in an intravenous drug user. IDCases 2017, 9, 77-78. [CrossRef]

11. Huang, Y.-T.; Jiang, J.-Y.; Hsu, M.-S.; Hsu, H.-S.; Liao, C.-H.; Hsueh, P.-R. The prevalence of rectal carriage of Klebsiella pneumoniae amongst diabetic patients and their clinical relevance in Taiwan: A five-year prospective study. J. Microbiol. Immunol. Infect. 2018, 51, 510-518. [CrossRef]

12. Khodadadian, R.; Rahdar, H.A.; Javadi, A.; Safari, M.; Khorshidi, A. Detection of VIM-1 and IMP-1 genes in Klebsiella pneumoniae and relationship with biofilm formation. Microb. Pathog. 2018, 115, 25-30. [CrossRef] [PubMed]

13. Boniface, Y.; Jean-Pierre, N.; Philippe, S.; Félicien, A.; Dominique, S. Etude chimique et activités antimicrobiennes d'extraits volatils des feuilles et fruits de Xylopia aethiopica (DUNAL) A. Richard contre les pathogènes des denrées alimentaires. J. Soc. Ouest-Afr. Chim. 2010, 29, 19-27.

14. Kacaniova, M.; Vukovič, N.; Hleba, L.; Bobková, A.; Pavelková, A.; Rovná, K.; Arpasova, H. Antimicrobial and Antiradicals Activity of Origanum vulgare L. and Thymus Vulgaris Essential Oils. J. Microbiol. Biotechnol. Food Sci. 2012, 2, $263-271$.

15. Faleiro, L.; Miguel, G.; Guerrero, C.; Brito, J. Antimicrobial activity of essential oils of Rosmarinus officinalis L., Thymus mastichina (L) L. ssp Mastichina and Thymus albicans Hofmanns \& Link. Acta Hortic. 1999, 45-48. [CrossRef]

16. Alitonou, G.; Avlessi, F.; Sohounhloue, D.; Agnaniet, H.; Bessiere, J.-M.; Menut, C. Investigations on the essential oil of Cymbopogon giganteus from Benin for its potential use as an anti-inflammatory agent. Int. J. Aromather. 2006, 16, 37-41. [CrossRef] 
17. De Oliveira, J.R.; De Castro, V.C.; Vilela, P.D.G.F.; Camargo, S.E.A.; Carvalho, C.A.T.; Jorge, A.O.C.; De Oliveira, L.D. Cytotoxicity of Brazilian plant extracts against oral microorganisms of interest to dentistry. BMC Complement. Altern. Med. 2013, 13, 208. [CrossRef]

18. Rebey, I.B.; Bourgou, S.; Tounsi, M.S.; Fauconnier, M.L.; Ksouri, R. Phytochemical composition and antioxidant activity of Lavandula dentate extracts. J. New Sci. 2017, 39, 2096-2105.

19. Naghibi, F.; Mosadegh, M.; Mohammadi, M.S.; Ghorbani, A.B. Labiatae Family in Folk Medicine in Iran: From Ethnobotany to Pharmacology. Iran. J. Pharm. Res. 2005, 4, 63-79.

20. Ali, H.; Al-Khalifa, A.R.; Aouf, A.; Boukhebti, H.; Farouk, A. Effect of nanoencapsulation on volatile constituents, and antioxidant and anticancer activities of Algerian Origanum glandulosum Desf. essential oil. Sci. Rep. 2020, 10, 1-9. [CrossRef]

21. Bendahou, M.; Muselli, A.; Grignon-Dubois, M.; Benyoucef, M.; Desjobert, J.-M.; Bernardini, A.-F.; Costa, J. Antimicrobial activity and chemical composition of Origanum glandulosum Desf. essential oil and extract obtained by microwave extraction: Comparison with hydrodistillation. Food Chem. 2008, 106, 132-139. [CrossRef]

22. Bekhechi, C.; Atik-Bekkara, F.; Abdelouahid, D.E. Composition et activité antibactérienne des huiles essentielles d'Origanum glandulosum d'Algérie. Phytothérapie 2008, 6, 153-159. [CrossRef]

23. Belhattab, R.; Larous, L.; Figueiredo, A.C.; Santos, P.A.G.; Pedro, L.G. Origanum glandulosum Desf. grown wild in Algeria: Essential oil composition and glycosidic bound volatiles. Flavour Fragr. J. 2004, 20, 209-212. [CrossRef]

24. Mechergui, K.; Jaouadi, W.; Coelho, J.A.; Serra, M.C.; Khouja, M.L. Biological activities and oil properties of Origanum glandulosum Desf: A review. Phytothérapie 2015, 14, 102-108. [CrossRef]

25. Harfi, B.; Benahmed, A.; Karkour, L. Characterization of Origanum glandulosum Desf. Essential Oils Collected from Different Culture Conditions Towards Standardized ex situ Production. J. Essent. Oil Bear. Plants 2019, 22, 838-850. [CrossRef]

26. Algieri, F.; Rodriguez-Nogales, A.; Vezza, T.; Garrido-Mesa, J.; Mesa, N.G.; Utrilla, M.P.; González-Tejero, M.R.; Casares-Porcel, M.; Mesa, J.M.; Contreras, M.D.M.; et al. Anti-inflammatory activity of hydroalcoholic extracts of Lavandula dentata L. and Lavandula stoechas L. J. Ethnopharmacol. 2016, 190, 142-158. [CrossRef]

27. Bachiri, L.; Bammou, M.; Echchegadda, G.; Ibijbijen, J.; El Rhaffari, L.; Haloui, Z.; Nassiri, L. Composition Chimique et Activité Antimicrobienne des Huiles Essentielles de Deux Espèces de Lavande: Lavandula Dentata spp. Dentata et Lavandula Peduncultata spp. Pedunculata. Eur. Sci. J. ESJ 2017, 13, 293. [CrossRef]

28. Bachiri, L.; Echchegadda, G.; Ibijbijen, J.; Nassiri, L. Etude Phytochimique et Activité Antibactérienne de Deux Espèces de Lavande Autochtones Au Maroc: «Lavandula stoechas L. et Lavandula dentata L.». Eur. Sci. J. ESJ 2016, 12. [CrossRef]

29. Clevenger, J.F. Apparatus for the Determination of Volatile Oil. J. Am. Pharm. Assoc. 1928, 17, 345-349. [CrossRef]

30. Cheurfa, M.; Allem, R.; Sebaihia, M.; Belhireche, S. Effet de l'huile essentielle de Thymus vulgaris sur les bactéries pathogènes responsables de gastroentérites. Phytothérapie 2013, 11, 154-160. [CrossRef]

31. Bauer, A.W.; Kirby, W.M.; Sherris, J.C.; Turck, M. Antibiotic susceptibility testing by a standardized single disk method. Am. J. Clin. Pathol. 1966, 45, 493-496. [CrossRef]

32. Khadir, A.; Bendahou, M.; Benbelaid, F.; Abdoune, M.A.; Abdelouahid, D.E. Pouvoir antimicrobien de Thymus lanceolatus Desf., récolté en Algérie. Phytothérapie 2013, 11, 353-358. [CrossRef]

33. Bazargani, M.M.; Rohloff, J. Antibiofilm activity of essential oils and plant extracts against Staphylococcus aureus and Escherichia coli biofilms. Food Control 2016, 61, 156-164. [CrossRef]

34. Flamini, G.; Pistelli, L.; Nardoni, S.; Ebani, V.V.; Zinnai, A.; Mancianti, F.; Ascrizzi, R.; Pistelli, L. Essential Oil Composition and Biological Activity of "Pompia", a Sardinian Citrus Ecotype. Molecules 2019, 24, 908. [CrossRef] [PubMed]

35. Bajpai, V.K.; Sharma, A.; Baek, K.-H. Antibacterial mode of action of Cudrania tricuspidata fruit essential oil, affecting membrane permeability and surface characteristics of food-borne pathogens. Food Control 2013, 32, 582-590. [CrossRef]

36. Russi, S.; Maresca, V.; Zoppoli, P.; Aieta, M.; Marino, G.; Sgambato, A.; Ignomirelli, O.; Ciuffi, M.; Notarangelo, T.; Basile, A.; et al. Effect of Feijoa Sellowiana Acetonic Extract on Proliferation Inhibition and Apoptosis Induction in Human Gastric Cancer Cells. Appl. Sci. 2020, 10, 7756. [CrossRef]

37. Di Napoli, M.; Maresca, V.; Varcamonti, M.; Bruno, M.; Badalamenti, N.; Basile, A.; Zanfardino, A. (+)-(E)-Chrysanthenyl Acetate: A Molecule with Interesting Biological Properties Contained in the Anthemis secundiramea (Asteraceae) Flowers. Appl. Sci. 2020, 10, 6808. [CrossRef]

38. Boyle, W.; Chow, A. Isolation of Human Lymphocytes by a Ficoll Barrier Method. Transfusion 1969, 9, 151-155. [CrossRef]

39. Kol, R.; Friedlander, M.; Riklis, E.; Raveh, D. Separation of Human Lymphocytes on Ficoll-Paque Gradients: Stimulation of Cells and Depletion of a Concanavalin-A Responsive Radioresistant Subpopulation. Radiat. Res. 1983, 95, 108. [CrossRef]

40. Liu, Y.; Schubert, D. Cytotoxic Amyloid Peptides Inhibit Cellular 3-(4,5-Dimethylthiazol-2-yl)-2,5-Diphenyltetrazolium Bromide (MTT) Reduction by Enhancing MTT Formazan Exocytosis. J. Neurochem. 2002, 69, 2285-2293. [CrossRef]

41. Notariale, R.; Basile, A.; Montana, E.; Romano, N.C.; Cacciapuoti, M.G.; Aliberti, F.; Gesuele, R.; De Ruberto, F.; Sorbo, S.; Tenore, G.C.; et al. Protamine-like proteins have bactericidal activity. The first evidence in Mytilus galloprovincialis. Acta Biochim. Pol. 2018, 65, 585-594. [CrossRef] [PubMed]

42. Manna, A.; Saha, P.; Sarkar, A.; Mukhopadhyay, D.; Bauri, A.K.; Kumar, D.; Das, P.; Chattopadhyay, S.; Chatterjee, M. Malabaricone-A Induces A Redox Imbalance That Mediates Apoptosis in U937 Cell Line. PLoS ONE 2012, 7, e36938. [CrossRef] [PubMed] 
43. Mohamed, S.B.; Eddine, A.D. Antibacterial Activity of Essential Oils of Some Algerian Aromatic Plants Against Multidrug Resistant Bacteria. J. Essent. Oil Bear. Plants 2010, 13, 362-370. [CrossRef]

44. Ouedrhiri, W.; Mounyr, B.; Harki, E.H.; Moja, S.; Greche, H. Synergistic antimicrobial activity of two binary combinations of marjoram, lavender, and wild thyme essential oils. Int. J. Food Prop. 2017, 20, 3149-3158. [CrossRef]

45. Dammak, I.; Hamdi, Z.; El Euch, S.K.; Zemni, H.; Mliki, A.; Hassouna, M.; Lasram, S. Evaluation of antifungal and antiochratoxigenic activities of Salvia officinalis, Lavandula dentata and Laurus nobilis essential oils and a major monoterpene constituent 1,8-cineole against Aspergillus carbonarius. Ind. Crop. Prod. 2019, 128, 85-93. [CrossRef]

46. Dob, T.; Dahmane, D.; Tayeb, B.; Chelghoum, C. Chemical composition of the essential oil of Lavandula dentata L. from Algeria. Int. J. Aromather. 2005, 15, 110-114. [CrossRef]

47. Silva-Flores, P.G.; Pérez-López, L.A.; Rivas-Galindo, V.M.; Paniagua-Vega, D.; Galindo-Rodríguez, S.A.; Álvarez-Román, R. Simultaneous GC-FID Quantification of Main Components of Rosmarinus officinalis L. and Lavandula dentata Essential Oils in Polymeric Nanocapsules for Antioxidant Application. J. Anal. Methods Chem. 2019, 2019, 1-9. [CrossRef] [PubMed]

48. Nabet, N.; Boudries, H.; Chougui, N.; Loupassaki, S.; Souagui, S.; Burló, F.; Hernández, F.; Carbonell-Barrachina, Á.A.; Madani, K.; Larbat, R. Biological activities and secondary compound composition from Crithmum maritimum aerial parts. Int. J. Food Prop. 2016, 20, 1843-1855. [CrossRef]

49. Gonçalves, M.; Cruz, M.; Cavaleiro, C.; Lopes, M.; Salgueiro, L. Chemical, antifungal and cytotoxic evaluation of the essential oil of Thymus zygis subsp. sylvestris. Ind. Crop. Prod. 2010, 32, 70-75. [CrossRef]

50. Nikolic, M.; Jovanović, K.K.; Marković, T.; Marković, D.; Gligorijević, N.; Radulović, S.; Soković, M. Chemical composition, antimicrobial, and cytotoxic properties of five Lamiaceae essential oils. Ind. Crop. Prod. 2014, 61, 225-232. [CrossRef]

51. Dutra, T.V.; Castro, J.C.; de Menezes, J.L.; Ramos, T.R.; Prado, I.N.D.; Machinski, M.; Mikcha, J.M.G.; Filho, B.A.D.A. Bioactivity of oregano (Origanum vulgare) essential oil against Alicyclobacillus spp. Ind. Crop. Prod. 2019, 129, 345-349. [CrossRef]

52. Hernández-González, M.; Berumen, C.P.; Ruíz, H.S.; Salazar, C.R.; Paz, J.H.; Olivas-Armendáriz, I.; Martel-Estrada, S.; González, C.R. Polysuccinimide functionalized with oregano's essential oil extracts, an antimicrobial extended release bio-material. Mater. Lett. 2017, 191, 73-76. [CrossRef]

53. Btissam, R.; Fatima, E.M.; Kamal, E.; Hassane, G.; Mohamed, N. Composition and Antibacterial Activity of Hydro-Alcohol and Aqueous Extracts Obtained from the Lamiaceae Family. Pharmacogn. J. 2017, 10, 81-91. [CrossRef]

54. Yang, S.-K.; Yusoff, K.; Thomas, W.; Akseer, R.; Alhosani, M.S.; Abushelaibi, A.; Lim, E.; Lai, K.-S. Lavender essential oil induces oxidative stress which modifies the bacterial membrane permeability of carbapenemase producing Klebsiella pneumoniae. Sci. Rep. 2020, 10, 819. [CrossRef] [PubMed]

55. Heydari, M.; Zanfardino, A.; Taleei, A.; Bushehri, A.A.S.; Hadian, J.; Maresca, V.; Sorbo, S.; Di Napoli, M.; Varcamonti, M.; Basile, A.; et al. Effect of Heat Stress on Yield, Monoterpene Content and Antibacterial Activity of Essential Oils of Mentha x piperita var. Mitcham and Mentha arvensis var. piperascens. Molecules 2018, 23, 1903. [CrossRef] [PubMed]

56. Rasooli, I.; Rezaei, M.B.; Allameh, A. Ultrastructural studies on antimicrobial efficacy of thyme essential oils on Listeria monocytogenes. Int. J. Infect. Dis. 2006, 10, 236-241. [CrossRef]

57. Turgis, M.; Han, J.; Caillet, S.; Lacroix, M. Antimicrobial activity of mustard essential oil against Escherichia coli O157:H7 and Salmonella typhi. Food Control 2009, 20, 1073-1079. [CrossRef]

58. Paul, S.; Dubey, R.; Maheshwari, D.K.; Kang, S.C. Trachyspermum ammi (L.) fruit essential oil influencing on membrane permeability and surface characteristics in inhibiting food-borne pathogens. Food Control 2011, 22, 725-731. [CrossRef]

59. Diao, W.-R.; Hu, Q.-P.; Zhang, H.; Xu, J.-G. Chemical composition, antibacterial activity and mechanism of action of essential oil from seeds of fennel (Foeniculum vulgare Mill.). Food Control 2014, 35, 109-116. [CrossRef]

60. Llobet, E.; Campos, M.A.; Giménez, P.; Moranta, D.; Bengoechea, J.A. Analysis of the Networks Controlling the AntimicrobialPeptide-Dependent Induction of Klebsiella pneumoniae Virulence Factors. Infect. Immun. 2011, 79, 3718-3732. [CrossRef]

61. Sertel, S.; Eichhorn, T.; Plinkert, P.K.; Efferth, T. Cytotoxicity of Thymus vulgaris essential oil towards human oral cavity squamous cell carcinoma. Anticancer Res. 2011, 31, 81-87.

62. Giongo, J.L.; Vaucher, R.A.; Da Silva, A.S.; Oliveira, C.B.; De Mattos, C.B.; Baldissera, M.D.; Sagrillo, M.R.; Monteiro, S.G.; Custódio, D.L.; De Matos, M.S.; et al. Trypanocidal activity of the compounds present in Aniba canelilla oil against Trypanosoma evansi and its effects on viability of lymphocytes. Microb. Pathog. 2017, 103, 13-18. [CrossRef]

63. Abu-Darwish, M.S.; Cabral, C.; Ferreira, I.; Gonçalves, M.J.; Cavaleiro, C.; Cruz, M.T.; Al-Bdour, T.H.; Salgueiro, L. Essential Oil of Common Sage (Salvia officinalisL.) from Jordan: Assessment of Safety in Mammalian Cells and Its Antifungal and Anti-Inflammatory Potential. BioMed Res. Int. 2013, 2013, 1-9. [CrossRef]

64. Sinha, S.; Jothiramajayam, M.; Ghosh, M.; Mukherjee, A. Evaluation of toxicity of essential oils palmarosa, citronella, lemongrass and vetiver in human lymphocytes. Food Chem. Toxicol. 2014, 68, 71-77. [CrossRef]

65. Prashar, A.; Locke, I.C.; Evans, C.S. Cytotoxicity of lavender oil and its major components to human skin cells. Cell Prolif. 2004, 37, 221-229. [CrossRef] 